\title{
Voltage-dependent lonic Conductances of Type I Spiral Ganglion Cells from the Guinea Pig Inner Ear
}

\author{
J. Santos-Sacchi \\ Sections of Otolaryngology and Neurobiology, Yale University School of Medicine, New Haven, Connecticut 06510
}

Type I spiral ganglion cells provide the afferent innervation to the inner hair cells of the mammalian organ of Corti and project centrally to the cochlear nucleus. While single-unit studies conducted over the past several decades have provided a wealth of information concerning the response characteristics of these neurons and, to some extent, their receptor targets, little is known about the neuron's intrinsic electrical properties. These properties undeniably will contribute to the firing patterns induced by acoustic stimuli. Type I spiral ganglion cell somata from the guinea pig inner ear were acutely isolated and the voltage-dependent conductances were analyzed with the whole-cell voltage clamp. Under conditions that mimic the normal intra- and extracellular ionic environments, type I spiral ganglion cells demonstrate fast inward TTX-sensitive Na currents (whose current density varied markedly among cells) and somewhat more slowly developing outward K currents. Resting potentials averaged $-67.3 \mathrm{mV}$. Under current clamp, no spontaneous spike activity was noted, but short current injections produced graded action potentials with after hyperpolarizations lasting several milliseconds. The nondecaying outward $K$ current activated at potentials near rest and was characterized by a pronounced rectification. The kinetics of the $\mathrm{Na}$ and $\mathrm{K}$ currents were rapid. Maximum peak inward $\mathrm{Na}$ currents occurred within $400 \mu \mathrm{sec}$, between a voltage range of -10 and $0 \mathrm{mV}$, and inactivated within $4 \mathrm{msec}$. Recovery from inactivation was also rapid. At a holding potential of $-80 \mathrm{mV}$, the time constant for recovery from an inactivating voltage step to $-\mathbf{1 0} \mathrm{mV}$ was $2.16 \mathrm{msec}$. Above $-\mathbf{5 0} \mathrm{mV}$ outward $K$ currents reach half-maximal amplitude within 1.5 msec. In addition to these currents, a slow noninactivating TTX-sensitive inward current was observed that was blockable with $\mathrm{Cd}^{2+}$ or $\mathrm{Gd}^{3+}$. Problems encountered with blocking the tremendous outward $\mathrm{K}$ current hampered the characterization of this inward current. Similarities between the kinetics of ganglion cell currents and some of the rapid temporal characteristics of eighth nerve single-unit activity confirm the notion that intrinsic membrane properties help shape auditory neuron responses to sound.

[Key words: spiral ganglion cell, inner ear, voltage clamp, organ of Corti, eighth nerve, ionic currents]

\footnotetext{
Received Nov. 12, 1992; revised Jan. 25, 1993; accepted Mar. 2, 1993.

This work was supported by an NIDCD Research Career Development Award and NIH Grant DC00273. I thank Drs. G. Huang, L. Kaczmarek, and H. Sontheimer for comments on the manuscript, and M. Scott Herness for sharing unpublished data.

Correspondence should be addressed to Joseph Santos-Sacchi, Ph.D., Department of Surgery, Section of Otolaryngology, Yale School of Medicine, BML 244, 333 Cedar Street, New Haven, CT 06510.

Copyright $(1993$ Society for Neuroscience $0270-6474 / 93 / 133599-13 \$ 05.00 / 0$
}

A tremendous amount of information has been gathered on eighth nerve single-fiber activity (for reviews, see Javel, 1986; Ruggero, 1992), and this information has aided in understanding much of what is known about mammalian inner ear function. The afferent innervation pattern of the organ of Corti provides an anatomical clue to the receptor dichotomy present in this sensory organ (see Dallos, 1988). Nearly all afferent fibers (up to $95 \%$ ) innervate the inner hair cells; these fibers arise from type I spiral ganglion cells (Spoendlin, 1988). The remaining type II fibers contact outer hair cells. Because of the small number and diameter of type II eighth nerve fibers, the preponderance, if not all, of eighth nerve single-unit studies have necessarily focused upon type I cells. Consequently, early studies on type I units were often used to provide insights into the physiology of the inner hair cell. Subsequent, direct intracellular recordings from inner hair cells have corroborated some singleunit findings; for example, inner hair cells are as finely tuncd as eighth nerve fibers (Russell and Sellick, 1978; Dallos et al., 1982). Unfortunately, the interpretation of some single-unit data is difficult because synaptic and neuronal influences are uncharacterized. Few recordings from inner hair cell afferent synapses have been made (Palmer and Russell, 1986; Siegel and Dallos, 1986; Siegel, 1992), and only preliminary information concerning mammalian type I spiral ganglion cell voltage-dependent ionic conductances is available (Santos-Sacchi, 1989a, 1990). I report here on some of the voltage-dependent ionic conductances of type I spiral ganglion cells that may underlie the generation of single-fiber activity.

\section{Materials and Methods}

General. Guinea pigs were anesthetized with halothane and killed by cervical dislocation. The temporal bones were removed, and spiral ganglion cells were obtained nonenzymatically by crushing the cochlear modiolus and bony spiral lamina, followed by trituration in nominally calcium-free medium. The supernatant was transferred to a $700 \mu l$ perfusion chamber, and the cells allowed to settle onto a glass coverslip bottom. A modified Leibovitz medium $(\mathrm{NaCl}, 142.2 \mathrm{~mm}$ KCl, 5.37 $\mathrm{mm} ; \mathrm{CaCl}_{2}, 1.25 \mathrm{~mm} ; \mathrm{MgCl}_{2}, 1.48 \mathrm{~mm}$; HEPES, $5.0 \mathrm{~mm}$; dextrose, 5.0 $\mathrm{mm}$; $\mathrm{pH}$ 7.2) was used as the normal perfusate. Modifications to the extracellular medium are noted in figure captions, with $\mathrm{NaCl}$ adjusted to maintain osmolarity $(300 \mathrm{mOsm})$. Extracellular solutions were changed via two methods. A chamber perfusion system was used to exchange fresh medium constantly $(0.1-1 \mathrm{ml} / \mathrm{min})$. A more rapid and direct pipette perfusion system was used to perfuse selectively single cells under voltage clamp during continuous exchange of bulk medium via chamber perfusion (Santos-Sacchi, 1991a). All experiments were performed at room temperature $\left(\sim 23^{\circ} \mathrm{C}\right)$. Cell diameter was determined for each cell by averaging three measures at different axes. A Nikon Diaphot inverted microscope with Hoffmann optics was used to observe the cells during electrical recording, and all experiments were taped with a Panasonic AG6300 video recorder.

Electrical recording. Type I spiral ganglion cell somata were wholecell voltage clamped with a Dagan patch-clamp amplifier typically at holding potentials between -70 and $-80 \mathrm{mV}$, unless otherwise noted. 
Pipette solutions were composed of $140 \mathrm{~mm} \mathrm{KCl}$ or CsCl, 5 or $10 \mathrm{~mm}$ EGTA or BAPTA, $2 \mathrm{mM} \mathrm{MgCl}_{2}$, and $5 \mathrm{~mm}$ HEPES buffered to pH 7.2. Cell somata are normally myelinated, but over the course of the in vitro incubation the myelin is shed. The type I spiral ganglion cell outnumbers the type II cell by about 20:1, and type I spiral ganglion cells are about $20 \mu \mathrm{m}$ in diameter while type II cells are about $15 \mu \mathrm{m}$. The average cell size in this study was about $19 \mu \mathrm{m}$ (see Results). Given these facts and the fact that most recorded cells had residual myelin figures associated with the cell somata (only type I are myelinated), it is concluded that most, if not all, of the cells studied were type I.

Gigohm seals were made on the neuronal plasmalemma and electrode capacitance was compensated prior to whole-cell recording. Voltage-step studies were performed with an Axolab $1100 \mathrm{~A} / \mathrm{D}$ and D/A board (Axon Instruments, Foster City, CA) with associated software (pCLAMP). The software was modified to provide a continuous display of clamp time constant $(\tau)$, cell capacitance $\left(C_{m}\right)$, and resistance $\left(R_{m}\right)$, and series resistance $\left(R_{s}\right)$ between data collections. Leakage subtraction was performed with the $P /-4$ technique at holding potentials noted in figure captions. Currents were filtered with an 8-pole Bessel filter at 7 $\mathrm{kHz}$.

Series resistance and cell capacitance were determined from capacitive transients induced by small voltage steps. The membrane resistance (200-800 M 2 ) of spiral ganglion cells is not great enough to permit the use of a simple method (Marty and Neher, 1983) of determining series resistance and membrane capacitance under whole-cell voltage clamp. This problem of estimating series resistance was encountered by Yamaguchi and Ohmori (1990) while studying chick cochlear ganglion cells. The method employed here for these determinations is robust despite filter settings, and accurately takes into account the effects of series resistance on capacitance measures. It is based on the simple circuit model of the voltage-clamped cell, that is, an access resistance $\left(R_{s}\right)$ in series with a parallel combination of a membrane capacitance $\left(C_{m}\right)$ and resistance $\left(R_{m}\right)$.

For the model, the steady state $\left(I_{\infty}\right)$ and instantaneous $\left(I_{0}\right)$ current responses to a voltage step are defined as

$$
\begin{aligned}
I_{\infty} & =\frac{V_{c}}{R_{s}+R_{m}}, \\
I_{0} & =\frac{V_{c}}{R_{s}}
\end{aligned}
$$

with the exponentially decaying capacitive current given as

$$
I_{C_{m}}=\left(I_{0}-I_{\infty}\right) e^{-t / \tau},
$$

where

$$
\begin{aligned}
\tau & =R_{\|} C_{m}, \\
R_{\|} & =R_{m} R_{s} / R_{i n},
\end{aligned}
$$

and

$$
R_{i n}=R_{m}+R_{s}
$$

the input resistance readily obtained at steady state.

The charge moved is then obtained by integration

$$
\int_{0}^{\infty} I_{C_{m},} d t=Q=\frac{C_{m} R_{m}^{2} V_{c}}{R_{i n}^{2}}
$$

Solving for $C_{m}$,

$$
C_{m}=\frac{K_{i n}^{2}}{R_{m}^{2}} \frac{Q}{V_{c}}
$$

and utilizing Equations 4 and 8 , we obtain

$$
R_{s}=\frac{R_{i n} \tau V_{c}}{Q R_{i n}+\tau V_{c}}
$$

The time constant $(\tau)$ of the exponentially decaying current, and the charge moved $(Q)$ are little affected by filter settings as low as $2 \mathrm{kHz}$ (8-pole Bessel). Equation 8 had been identified and used by Mathias et al. (1981) to evaluate alternative explanations of nonlinear gating charge movement, and it is, in fact, the proper evaluation of cell capacitance for the cell model when the ratio of $R_{s}$ and $R_{r n}$ does not approach zero. In this article, series resistance was compensated electronically, and voltages were corrected for residual series resistance effects.

Steady state inactivation of $\mathrm{Na}$ currents was fit with a Boltzmann function,

$$
I_{\text {relative }}=\left[\frac{I_{\max }-I_{\min }}{1+\exp ^{\left[-z e\left(V-Y_{h}\right) / k T\right]}}\right]+I_{\min },
$$

where $V$ is the potential of an inactivating prepulse, $V_{h}$ is voltage at half-maximal inactivation, $e$ is electron charge, $k$ is Boltzmann's constant, $T$ is absolute temperature, $z$ is the valence, $I_{\max }$ is maximum $\mathrm{Na}$ current induced by a fixed depolarization step, and $I_{\min }$ is minimum current.

\section{Results}

Type I spiral ganglion cells, including cell somata, are normally enveloped by a myelin sheath. Immediately after isolation by trituration, cell somata remain myelinated; however, over the course of tens of minutes many cells shed this coating (Fig. 1), making the neuronal plasmalemma accessible to patch pipettes. After whole-cell configuration is attained, and following a few minutes to allow equilibration of the normal $\mathrm{KCl}$-containing pipette solution into the cells, resting potentials averaged -67.3 $\pm 5.7 \mathrm{mV}$ (mean $\pm \mathrm{SD} ; n=11$ ). The capacitance of the cells averaged $10.14 \pm 1.68 \mathrm{pF}(n=32)$ and agreed well with corresponding estimates $(11.3 \mathrm{pF})$ based on surface area calculated from the average cell diameter of $19.01 \pm 1.66 \mu \mathrm{m}(n=59)$.

Under conditions that mimic the normal intra- and extracellular environments, type I spiral ganglion cells demonstrate fast inward $\mathrm{Na}$ currents and more slowly developing outward $\mathrm{K}$ currents. Figure $2 A$ illustrates the whole-cell currents under these conditions. Under current clamp, no spontaneous activity was noted, and brief current injections only produced graded spikes (Fig. 2B). Afterhyperpolarizations lasting several milliseconds followed the current induced depolarizations. Longer current injections did not produce repetitive spiking.

The magnitude of the fast inward $\mathrm{Na}$ currents varied greatly across cells, some cells demonstrating none. Figure 3 illustrates outward $\mathrm{K}$ currents in a cell in which no inward $\mathrm{Na}$ currents were evoked from the holding potential of $-70 \mathrm{mV}$ (a few cells were found that required holding potentials more negative than $-80 \mathrm{mV}$ to reveal $\mathrm{Na}$ currents). The outward $\mathrm{K}$ currents in spiral ganglion somata are blockable by extracellular tetraethylammonium (TEA), or $\mathrm{Gd}^{3+}$, or intracellular Cs (but see below) and display fairly rapid onset kinetics, with little or no inactivation. Raising extracellular $\mathrm{K}$ levels above $100 \mathrm{~mm}$ reverses the current polarity. Figure 4 illustrates responses from another $\mathrm{KCl}$-loaded cell in which the fast inward $\mathrm{Na}$ currents were blocked with TTX. Outward rectification is pronounced and initiates near the resting potential. At $-43 \mathrm{mV}$ activation ensues within $360 \mu \mathrm{sec}$ after step onset (Fig. 4D). The voltage dependence of current onset kinetics was estimated by measuring the time required to reach half-maximal current amplitude (Fig. 4C). Above $-50 \mathrm{mV}$ outward currents reach half-maximal amplitude within $1.5 \mathrm{msec}$.

Reduction of extracellular $\mathrm{Ca}$ had profound effects upon the neural membrane; an extreme example, where Ca-free extracellular medium containing 2 mM EGTA was perfused onto the cell, is illustrated in Figure $5 \mathrm{~A}$. Removal of Ca caused a reversible reduction of the $K$ currents, a depolarizing shift in the zero current potential (opposite in sign to a potential charge screening effect), and an increase in the leakage conductance. [Armstrong and Miller (1990) showed that voltage-dependent $\mathrm{K}$ channels are adversely affected by removal of extracellular $\mathrm{Ca}$, causing the cell to become leaky and the channels to become nonselective. However, they determined that in the presence of $1 \mathrm{~mm}$ extracellular $\mathrm{K}$, this effect was absent. In the present 

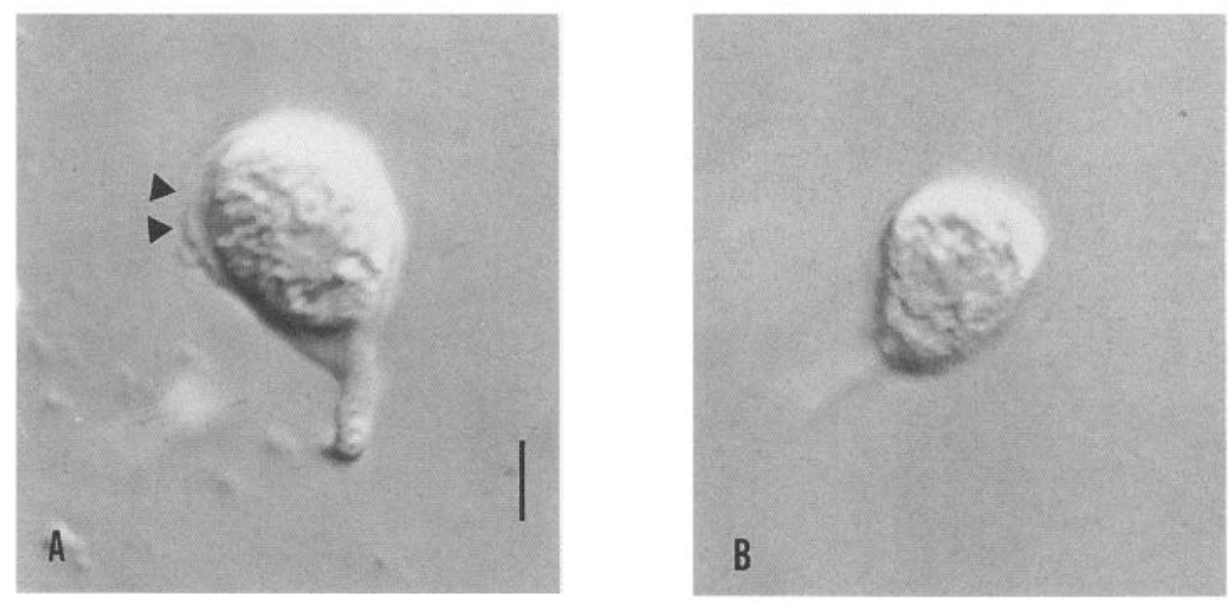

Figure 1. A, Spiral ganglion cell immediately after isolation. Myelin sheath can be observed enveloping the somata (arrowheads). B, Spiral ganglion cell that has lost its myelin sheath after incubation and whose neuronal plasmalem$\mathrm{ma}$ is accessible to patch pipettes. Scale bar, $7 \mu \mathrm{m}$.

experiments, $5 \mathrm{~mm} \mathrm{~K}$ was present in the extracellular medium, and the type of effect noted by Armstrong and Miller probably does not occur. Indeed, outward rectification is still robust.] $\mathrm{Gd}^{3+}(50 \mu \mathrm{M})$ substantially blocked outward currents in ganglion cells (Fig. $5 B, C$ ).

Fast inward $\mathrm{Na}$ currents were readily isolated when outward currents were blocked, and the $\mathrm{Na}$ currents could be totally blocked with TTX (100-300 nM). Figure 6 illustrates the current-voltage relation for a spiral ganglion cell before and during
TTX perfusion. In addition, the fast inward current was abolished by replacement of extracellular $\mathrm{Na}$ by Tris or TEA. Maximum peak inward $\mathrm{Na}$ currents occurred within $400 \mu \mathrm{sec}$, between a voltage range of -10 and $0 \mathrm{mV}$, and inactivated within $4 \mathrm{msec}$. Single exponential fits to the decaying $\mathrm{Na}$ currents indicate a voltage-dependent inactivation (Fig. 7A). Averaged inactivation time constants for a group of spiral ganglion cells ranged from $0.8 \mathrm{msec}$ at $-23 \mathrm{mV}$ to $0.3 \mathrm{msec}$ at $+25 \mathrm{mV}$. The time required for $\mathrm{Na}$ currents to reach half-peak levels was also

A

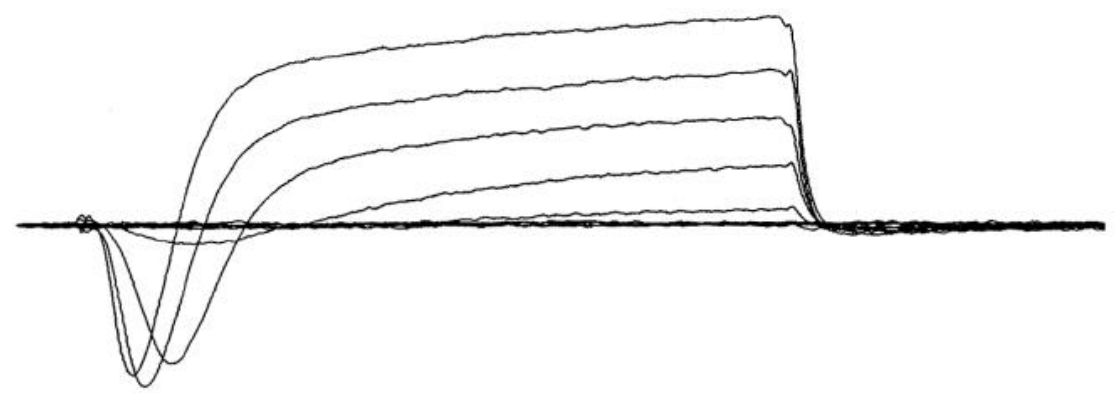

${ }_{n \mathrm{~A}}^{2}$

$0.8 \mathrm{~ms}$

B

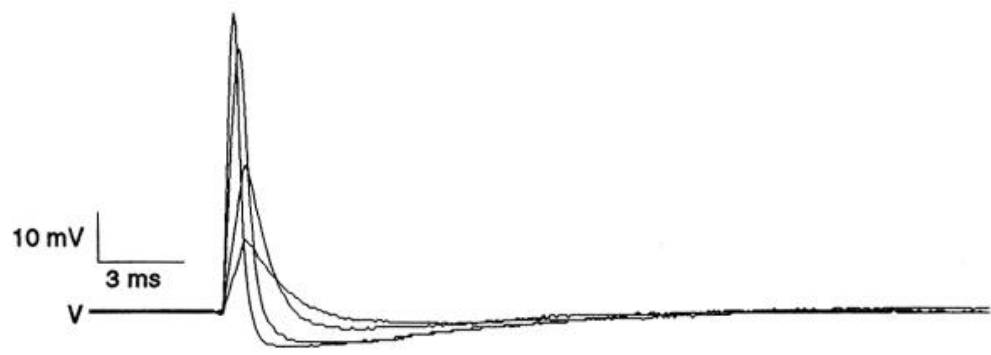

i

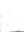

Figure 2. A, Isolated spiral ganglion cell under whole-cell voltage clamp. $\mathrm{Pi}-$ pette solution was normal $\mathrm{KCl}$ solution. Extracellular solution was modified Leibovitz. Cell was held at $-80 \mathrm{mV}$ and nominally stepped in $10 \mathrm{mV}$ increments from $-100 \mathrm{mV}$ to $-10 \mathrm{mV}$. Note fast inward $\mathrm{Na}$ currents followed by outward $\mathrm{K}^{+}$currents. Leakage subtracted. Clamp $\tau, 69 \mu \mathrm{sec}$; series resistance, $6.1 \mathrm{M} \Omega$; holding current, $-62 \mathrm{pA}$. $B$, Same cell under current clamp. Current pulse injection $(i ; 0.8 \mathrm{msec}$ at 0.5 , $1,2.5$, and $4 \mathrm{nA}$ ) initiated a depolarization $(v)$ from the resting potential that was graded with step size. Respective times to peak depolarization were 0.72 , $0.72,0.56$, and $0.40 \mathrm{msec}$. Note the increasingly rapid repolarization and afterhyperpolarization as a function of spike amplitude due to the inactivation of $\mathrm{Na}$ conductance and activation of $\mathrm{K}$ conductance. Membrane potential returned to baseline within about $18 \mathrm{msec}$. Voltage drop across electrode, based on the instantaneous step in voltage, was subtracted during pulse width. Resting potential was $-64.4 \mathrm{mV}$. 
Figure 3. Isolated spiral ganglion cell under whole-cell voltage clamp. Cell was held at $-70 \mathrm{mV}$ and nominally stepped in $5 \mathrm{mV}$ increments through the voltage range of -115 to $-25 \mathrm{mV}$. Plotted outward $\mathrm{K}^{+}$currents were determined from the final $10 \mathrm{msec}$ average of each trace (inset, upper left). KCI pipette, Leibovitz medium. Na currents were absent in this cell and may have been due partly to steady state inactivation at this holding potential (see Results). No leakage subtraction. Corrected for an uncompensated series resistance of 8 $\mathrm{M} \Omega$. Holding current, $37 \mathrm{pA}$.

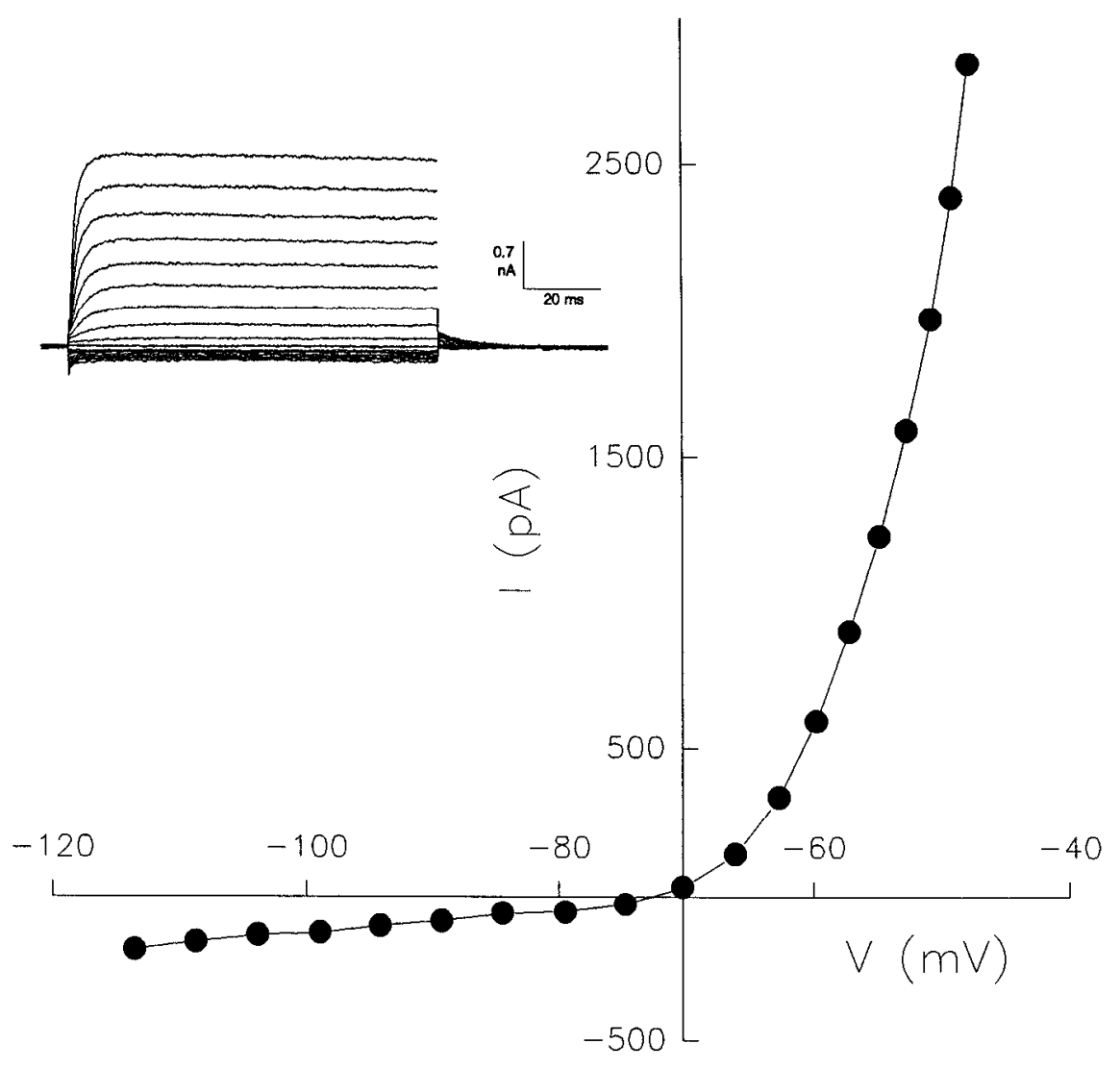

under these conditions (see Discussion). This sustained inward current and associated tail current are shown in Figure 11 to be somewhat reduced in magnitude by $50 \mu \mathrm{M} \mathrm{Cd}^{2+}$ and totally blocked by $50 \mu \mathrm{M} \mathrm{Gd}{ }^{3+}$. Cobalt ( $2 \mathrm{~mm}$ ) in the absence of extracellular $\mathrm{Ca}^{2+}$ also abolishes this current. These data provide evidence for a component calcium conductance that is activated near the resting potential. Interestingly, an increased intracellular Ca concentration prolongs the decay of the associated tail currents (which are TEA blockable) and reduced extracellular $\mathrm{Ca}$ speeds the decay, possibly indicating that $\mathrm{K}(\mathrm{Ca})$ channels may be involved in generating the tail currents.

It was observed that not only did TTX block fast inward $\mathrm{Na}$ currents but it reduced the magnitude of the slow inward currents in a reversible manner as well (Fig. 12a,b). The reduction was not due to a decrease in a noninactivating Na current, since replacement of extracellular $\mathrm{Na}$ by Tris abolished the fast inward Na current, but did not affect the sustained inward currents (Fig. $12 c)$.

\section{Discussion}

Firing patterns and firing rates are considered important aspects of auditory frequency and intensity coding (Ruggero, 1992). The mammalian auditory nerve encodes very high-frequency information. Auditory sensitivity of the guinea pig extends above 40 $\mathrm{kHz}$, and that of the bat above $100 \mathrm{kHz}$. Indeed, Javel (1986) has commented that within a few milliseconds after the initiation of an acoustic stimulus firing rates can approach 2000 spikes/sec in the cat. Average steady rates have been measured up to about 400 spikes/sec. Necessarily, eighth-nerve fibers must detect and process inner hair cell activity at a tremendous pace to faithfully transmit receptor potential information centrally. In this study, it is demonstrated that type I spiral ganglion cells
mM TEA solutions or in CsF-loaded cells. It seems likely that the tremendous outward $\mathrm{K}$ current was not completely blocked 
A

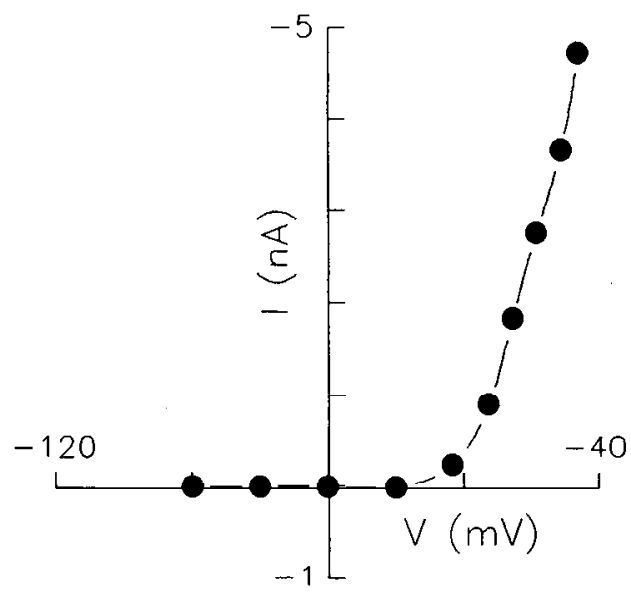

C

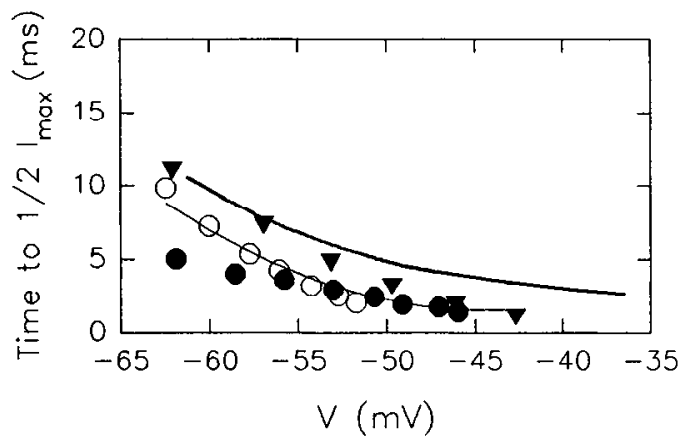

B

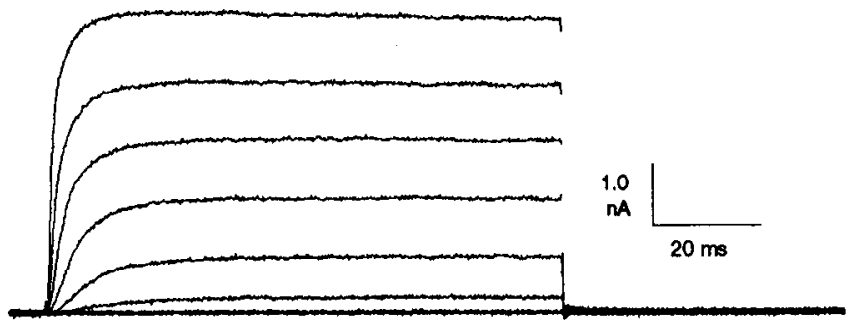

D

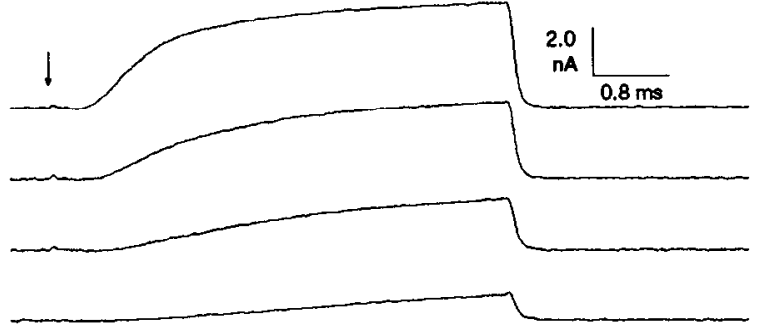

Figure 4. Isolated spiral ganglion cell under whole-cell voltage clamp. Cell was held at $-80 \mathrm{mV}$ and nominally stepped in $10 \mathrm{mV}$ increments through the voltage range of -110 to $-10 \mathrm{mV} . I-V$ curve $(A)$ is corrected for series resistance effects, and plotted outward $\mathrm{K}^{+}$currents were determined from the final $10 \mathrm{msec}$ average of each trace $(B)$. The times to reach half-maximal $\mathrm{K}$ current levels $(C$, plotted against corrected steady state voltage) were obtained from the traces in Figures 3-5 (symbols with thin fitted line). Marked voltage dependence is evident. The thick line represents data obtained from Yamaguchi and Ohmori (1990, their Fig. 3). Data collection at a higher sampling rate $(D)$ illustrates delay in onset of outward currents. $\mathrm{KCl}$ pipette, Leibovitz medium with $100 \mathrm{nM}$ TTX. Leakage subtraction. Corrected for an uncompensated series resistance of $7 \mathrm{M} \Omega$. Clamp $\tau, 62 \mu \mathrm{sec}$; holding current, $40 \mathrm{pA}$.

A

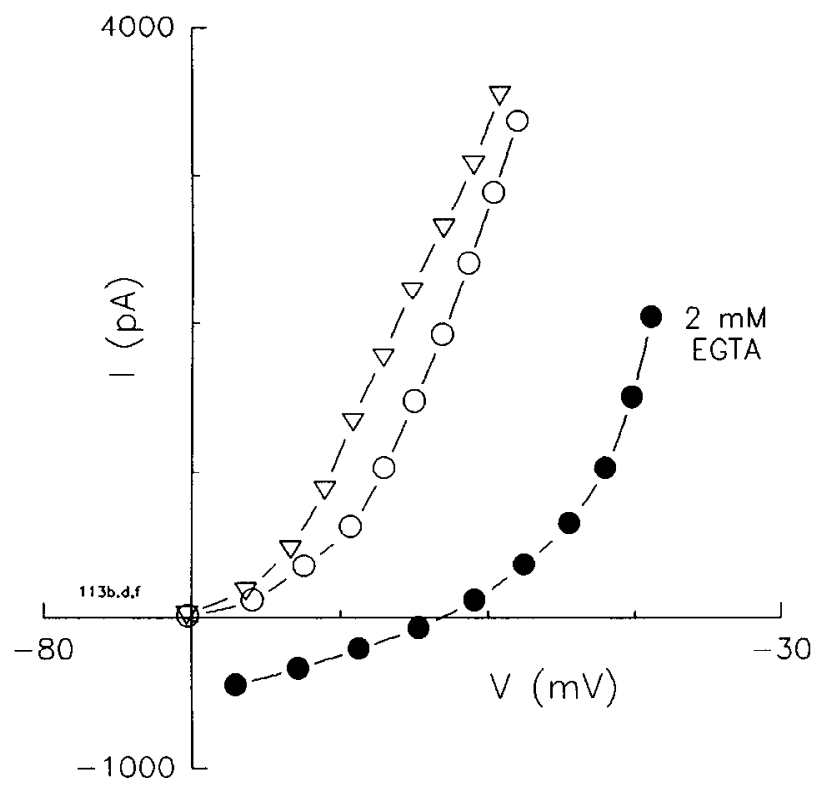

B

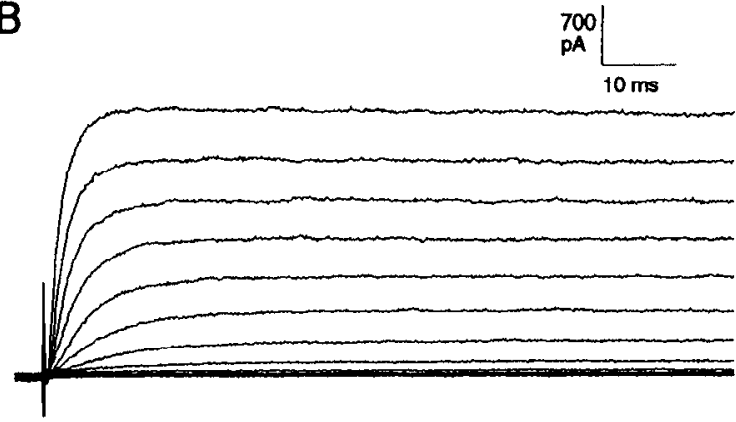

C

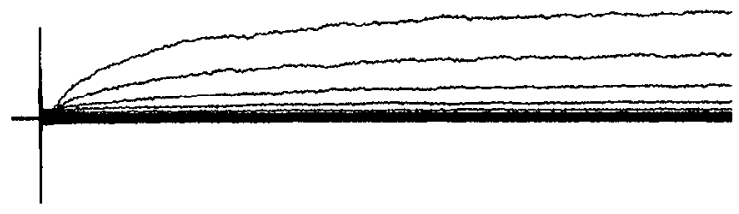

Figure 5. A, Isolated spiral ganglion cell under whole-cell voltage clamp. $I-V$ plots of outward $\mathrm{K}^{+}$currents were determined before (open circles) and after (triangles) removal of extracellular Ca (solid circles; no added Ca and 2 mM EGTA), at a holding potential of $-70 \mathrm{mV}$. Plotted outward $\mathrm{K}$ currents were determined from the final $10 \mathrm{msec}$ average of each $100 \mathrm{msec}$ trace. Note reversible drop in zero current potential and input resistance. No leakage subtraction. Corrected for an uncompensated series resistance of $6.8 \mathrm{M} \Omega . B$ and $C$, Traces depicting outward $\mathrm{K}$ currents in another ganglion cell after recovery from $(B)$ and during $(C)$ perfusion of normal extracellular medium supplemented with $50 \mu \mathrm{M} \mathrm{Gd}^{3+}$. Holding potential was $-70 \mathrm{mV}$, and steps were from -100 to $-30 \mathrm{mV}$ (nominal). Holding current: $B,-81.7 \mathrm{pA} ; C,-66.4 \mathrm{pA}$. 
Figure 6. Fast Na currents from a spiral ganglion cell whose outward currents had been blocked. Intracellular solution contained $140 \mathrm{~mm} \mathrm{CsCl}$, supplemented with $5 \mathrm{~mm} \mathrm{NaCl}$. Extracellular solution contained $20 \mathrm{mM}$ TEA,

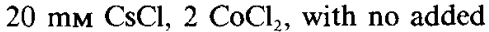
$\mathrm{Ca}$ and $\mathrm{NaCl}$ appropriately adjusted. Peak inward currents occurred near 0 $\mathrm{mV}$. Leakage subtracted. Corrected for an uncompensated series resistance of 4.98 M ; voltage corrections were made based on nonleakage subtracted peak current magnitudes. Holding current was $-43 \mathrm{pA}$; clamp t was $29 \mu \mathrm{sec}$. Insets: $a, \mathrm{Na}$ currents prior to block; $b$, block of Na currents by 300 nM TTX. Traces were digitally filtered for presentation at $3.2 \mathrm{kHz}$.

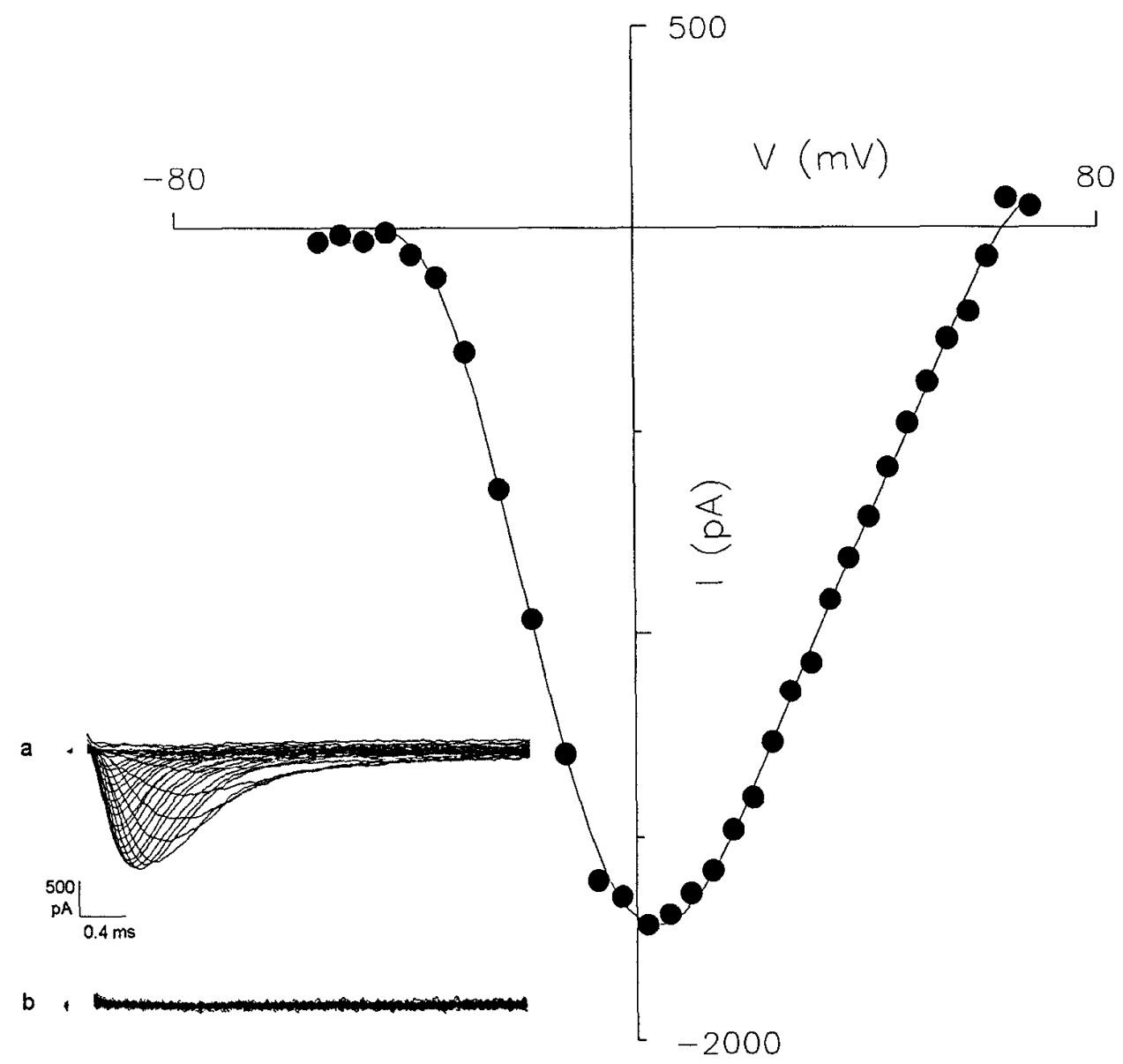

possess the required conductances and kinetics to account for such high-frequency phenomena.

\section{Resting potential of spiral ganglion cells}

Type I spiral ganglion cell somata have resting potentials near $-70 \mathrm{mV}$ when loaded with $140 \mathrm{~mm} \mathrm{KCl}$. Palmer and Russell (1986) measured membrane potentials in type I afferent terminals in the guinea pig, which ranged from -40 to $-60 \mathrm{mV}$. The activation of $\mathrm{K}$ currents near these potentials and the observation that removal of extracellular $\mathrm{Ca}$ shifts zero current levels suggest that the resting potential may be maintained partly by a Ca-activated $\mathrm{K}$ conductance. The likelihood of the existence of a Ca-activated $\mathrm{K}$ conductance is strengthened by the observation of prolongation of TEA-blockable tail currents associated with increased levels of intracellular $\mathrm{Ca}$. Single-channel Ca-activated $\mathrm{K}$ currents have been measured in cultured goldfish auditory ganglia (Davis et al., 1989). The effect of calcium removal on the ganglion cell is in marked contrast to the effects of extracellular calcium removal on outer hair cell outward $\mathrm{K}$ currents and zero current levels, where little or no effect is seen (Santos-Sacchi, 1989c). However, the block of ganglion cell outward $\mathrm{K}$ currents by $\mathrm{Gd}^{3+}$ is similar to the trivalent cation's effects on outer hair cells and Deiters cells from the organ of Corti (Santos-Sacchi, 1991a).

\section{Na channels in spiral ganglion cell somata}

The bipolar spiral ganglion somata have input resistances around $500 \mathrm{M} \Omega$, and capacitances around $10 \mathrm{pF}$, giving a membrane time constant of about $5 \mathrm{msec}$ near $-80 \mathrm{mV}$. This is similar to that observed in chick cochlear ganglion cells (Yamaguchi and Ohmori, 1990). This time constant is fairly slow, and might interfere with spike transmission through ganglion cell somata. Mcans must exist to permit the unobstructed transmission of spike activity containing timing information across the $20 \mu \mathrm{m}$ somata of the eighth-nerve fiber, as temporal coding is important for many aspects of auditory function, including sound localization. If resting potentials are more depolarized than -70 $\mathrm{mV}$ in vivo (see above), then the activation of the $\mathrm{K}$ conductance will dramatically reduce the membrane time constant and increase timing resolution. More notably, $\mathrm{Na}$ conductances are present in cell somata, indicating that the somata are excitable. Thus, while Na channels are usually restricted to neuronal nodal regions (Waxman and Ritchie, 1985; Black et al., 1990; Gilley et al., 1990), it is possible that $\mathrm{Na}$ channels are normally present in spiral ganglion cell somata and are required for fast throughput with little attenuation. Fast $\mathrm{Na}$ currents are also observed in chick cochlear ganglion cells (Yamaguchi and Ohmori, 1990) and acutely isolated cells of the cochlear nucleus (Manis and Marx, 1991).

It cannot be ruled out, however, that cell somata actually have few $\mathrm{Na}$ channels, and during isolation cellular processes are retracted into the somata with differing amounts of nodal membrane. The variability of Na channel density in cell somata is great, and differing degrees of nodal resorption may account for it. Another possibility is that $\mathrm{Na}$ channels destined for remote sites are incorporated into somata plasmalemma during isola- 


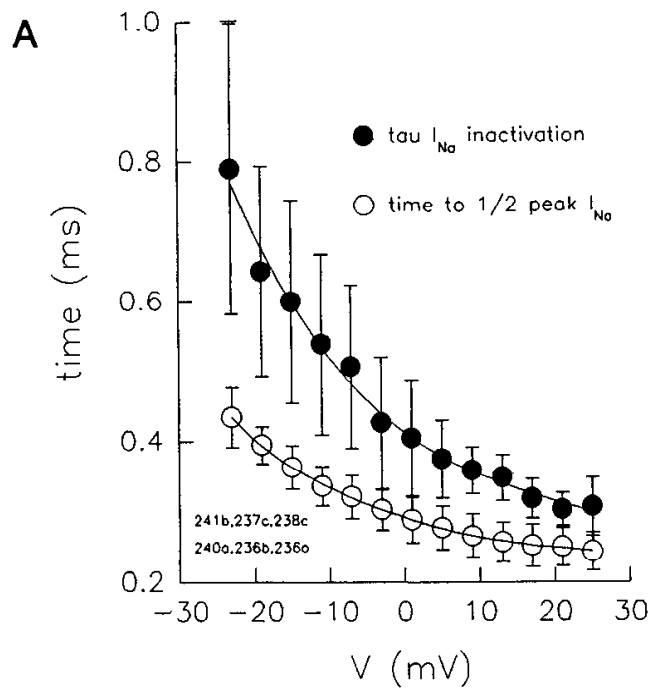

B

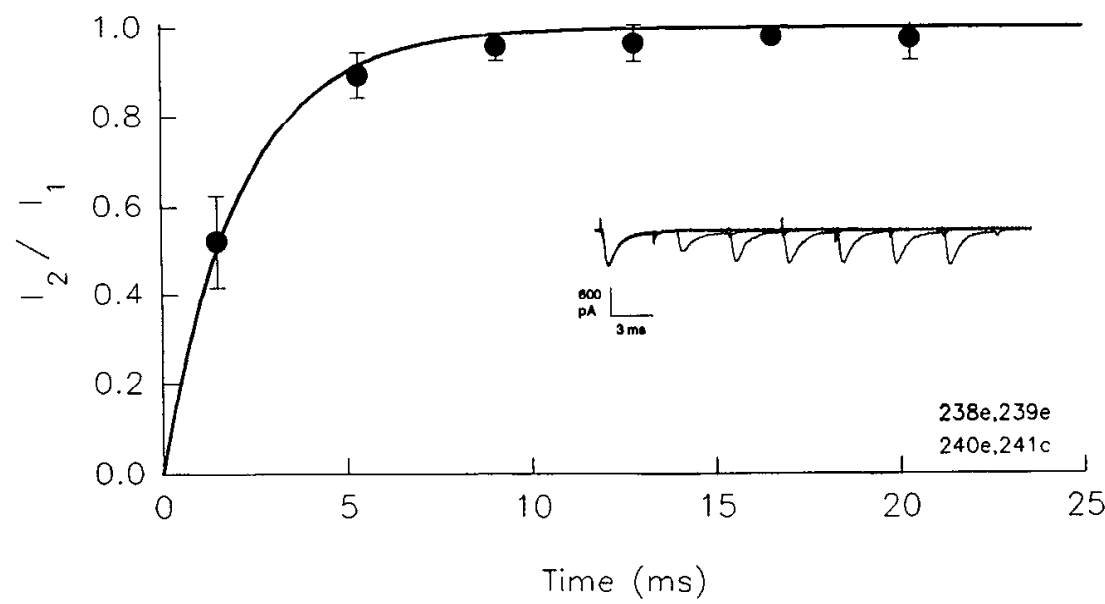

Figure 7. $A$, Averages and standard deviations $(n=6)$ of $\mathrm{Na}$ current inactivation (single exponential fit to decaying phase; filled circles) and time to half-peak inward $\mathrm{Na}$ current (circles) versus nominal step voltagc. Intraccllular solution contained $140 \mathrm{~mm} \mathrm{CsCl}$. Extracellular solution contained $20 \mathrm{~mm}$ TEA, $20 \mathrm{~mm} \mathrm{CsCl}, 2 \mathrm{CoCl}_{2}$, with no added $\mathrm{Ca}$ and $\mathrm{NaCl}$ appropriately adjusted. Clamp $\tau$ was $0.033 \pm 0.006$ msec. Holding potential was $-80 \mathrm{mV}$. $B$, Recovery of $\mathrm{Na}$ currents from inactivation. An initial $3.5 \mathrm{msec}$ voltage step to $-10 \mathrm{mV}$ was followed at increasing time intervals by the same stimulus. Peak inward current magnitude evoked by the second pulse is plotted relative to the first response. Rest periods of $4 \mathrm{sec}$ were given between cach trail. Average and standard deviations are plotted $(n=4)$. Time constant of recovery was $2.16 \mathrm{msec}$. Holding potential was $-80 \mathrm{mV}$. Solutions were as in Figure $7 A$. Inset, Example of current traces; six trials are superimposed. tion. Variation in $\mathrm{Na}$ channel density may reflect differing degrees of $\mathrm{Na}$ channel production in the course of normal turnover, since spiral ganglion cells vary markedly in length.

\section{Is the spiral ganglion cell soma simply another internode?}

Because the type I cell soma of the guinea pig spiral ganglion is enveloped by a myelin sheath, one may conceive of it as an internode inserted along the course of the myelinated eighthnerve fiber. The myelin sheath of the spiral ganglion cell is not characteristic of all mammalian species. For example, in the human there is typically no sheath (Ota and Kimura, 1980) and in the monkey it is very poorly developed (Kimura et al., 1987). In fact, the number of lamellae in those species having sheaths is considerably lower than that surrounding adjacent internodes (Kellerhals et al., 1967; Spoendlin, 1971; Robertson, 1976). These are not trivial observations. That is, since the number of lamellae is inversely proportional to internode capacity and directly proportional to internode resistance, it is not known how a partially myelinated soma ( $\sim 20 \mu \mathrm{m}$ in diameter) affects conduction in auditory nerve fibers. Nevertheless, the concept that type I somata function as internodes should be considered in understanding the ability of the fiber to transmit impulse trains across a potential somal filter. The distribution of ionic channels within mammalian myelinated fibers is not randomspecific ionic conductances are restricted to distinct neurolemmal domains (Waxman and Ritchie, 1985). Whereas in mammals nodal regions possess only $\mathrm{Na}$ channels, myelinatcd internodal regions possess voltage-dependent $\mathrm{K}$ and possibly $\mathrm{Na}$ channels (Chiu and Schwartz, 1987). What effects might the voltage and kinetic characteristics of the spiral ganglion soma conductances have on somal impulse throughput? Indeed, if the conductances are representative of other internodal regions along the eighth-nerve fiber, what general consequences might their characteristics have for auditory neural transmission?

It has been speculated that the $\mathrm{K}$ conductance in the internodal region of the mammalian nerve fiber maintains the internodal and nodal resting membrane potential, especially if the conductance is active near rest (Chiu and Ritchie, 1984). The activation potential (near $-70 \mathrm{mV}$ ) of the spiral ganglion cell $\mathrm{K}$ conductance is consistent with this scheme. A consequence of $\mathrm{K}$ channel activation near rest is a reduced membrane time constant, that is, a reduction of the filtering capacity of the 
Figure 8. The effect of holding potential on Na current magnitude. Reducing holding potential from $-80 \mathrm{mV}$ to -60 $\mathrm{mV}$ inactivates nearly all $\mathrm{Na}$ channels in spiral ganglion cells. Voltage dependence remains constant. Holding current at $-80 \mathrm{mV}$ was $-124.5 \mathrm{pA}$. Corrected for an uncompensated series resistance of $4.79 \mathrm{M} \Omega$. Clamp $\tau$ was $0.031 \mathrm{msec}$. Inset, Current traces digitally filtered at $3.2 \mathrm{kHz}$ for presentation.

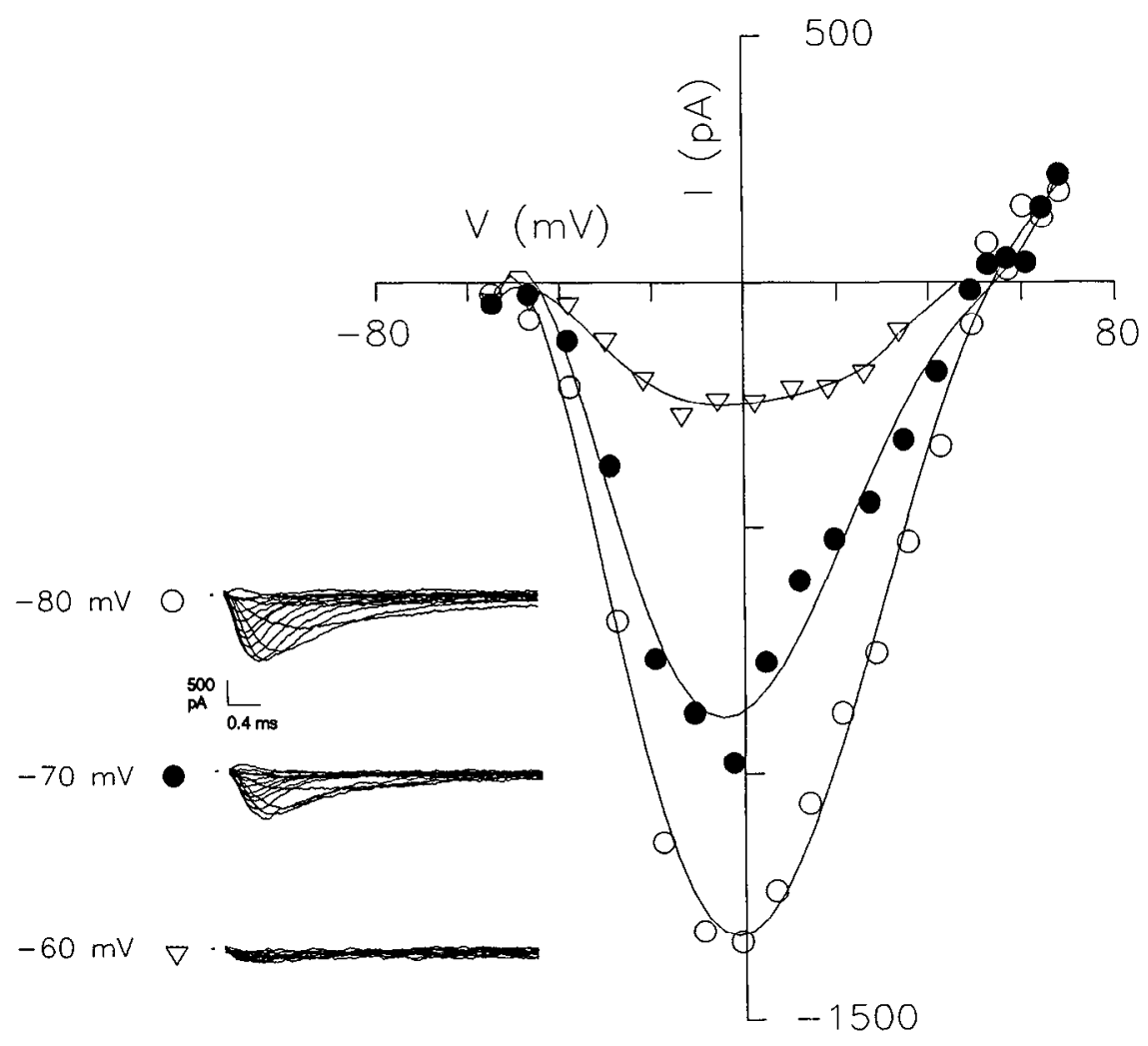

internode. However, this resting conductance will also limit electrotonic spread between nodes, which is requisite for saltatory conduction.

A more important issue raised by Chiu and Ritchie (1984) is the contribution of internodal $\mathrm{K}$ conductances to the repolarization of nodal membrane. Following an action potential, the nodal membrane must repolarize to permit recovery from $\mathrm{Na}$ channel inactivation and restoration of excitability. These authors convincingly argue that electrotonic spread of depolarization from nodal to internodal membrane can activate voltagedependent internodal $\mathrm{K}$ conductances that effectively repolarize nodal membrane. The characteristics of this conductance may help limit the duration of action potentials and reduce the possibility of repetitive afterspiking (Baker et al., 1987; Black et al., 1990). Currently, it is thought that discharge of capacitive current through leakage pathways between the myelin sheath and axonal membrane promotes an afterdepolarization following the action potential (Barrett and Barrett, 1982; Baker et al., 1987). This afterdepolarization is believed to promote repetitive spiking, as it will lower spike threshold. In fact, Black et al. (1990) have demonstrated that blockade of internodal K conductances elicits repetitive afterspiking, and David et al. (1992) have shown that action potentials can activate internodal $\mathrm{K}$ conductances. By evaluating the myelinated axon model of Barrett and Barrett (1982) it is clear that an increased conductance of internodal axonal membrane will limit the duration of this afterdepolarization. In fact, the more rapidly the conductances are activated, the more quickly the afterdepolarization is dissipated. For fibers that conduct information in the precise timing of action potentials, it is reasonable that $\mathrm{K}$ conductances should possess rapid activation kinetics, or else slow repolarization will distort the timing of later signals. In the eighth nerve, fibers are known to phase lock to acoustic frequencies as high as $4 \mathrm{kHz}$, indicating that the temporal resolution must be great. Phase locking is known to be important for one mechanism of frequency discrimination (see Javel, 1986). The kinetics of spiral ganglion cell $\mathrm{K}$ conductances are faster than those of internodal membrane of rabbit myelinated sciatic nerve fibers, whose firing rates do not approach that of eighth-nerve fibers [e.g., at -25 $\mathrm{mV}$, time to half-peak $\mathrm{K}$ current is about $5 \mathrm{msec}$ in the sciatic nerve (Chiu and Ritchie, 1984), whereas at $-43 \mathrm{mV}$ the value is $1 \mathrm{msec}$ for the spiral ganglion cell; temperatures are comparable]. The fast recovery of $\mathrm{Na}$ channel inactivation in the spiral ganglion cell also indicates that the effects of rapid $\mathrm{K}$ channel activation will be registered quickly. It appears, then, that even with the spiral ganglion cell soma viewed as an internode among other internodes, the voltage dependence and kinetics of the intrinsic membrane conductances contribute to the temporal characteristics of auditory nerve performance.

\section{Comparison of spiral ganglion cell kinetics with those of other primary sensory neurons}

The kinetics of ionic channels are temperature dependent (Hodgkin and Huxley, 1952; Frankenhaeuser and Moore, 1963). Thus, the results presented in the present report at room temperature $\left(\sim 23^{\circ} \mathrm{C}\right)$ should be interpreted accordingly. The temperature dependence of channel kinetics typically has a temperature coefficient $\left(Q_{10}\right)$ of about 3 (Frankenhaeuser and Moore, 1963; Huguenard et al., 1991). Measures at higher, in vivo, temperatures will be faster by a factor of 3 for each $10^{\circ} \mathrm{C}$ increase. Keeping temperature effects in mind, it is illuminating to compare the kinetics of $\mathrm{Na}$ and $\mathrm{K}$ conductances of the guinea pig spiral ganglion cell to comparable results obtained from other mammalian primary sensory systems. In addition, a comparison is made to data obtained from a nonmammalian cochlear ganglion cell, that of the chick (Yamaguchi and Ohmori, 1990). 
A

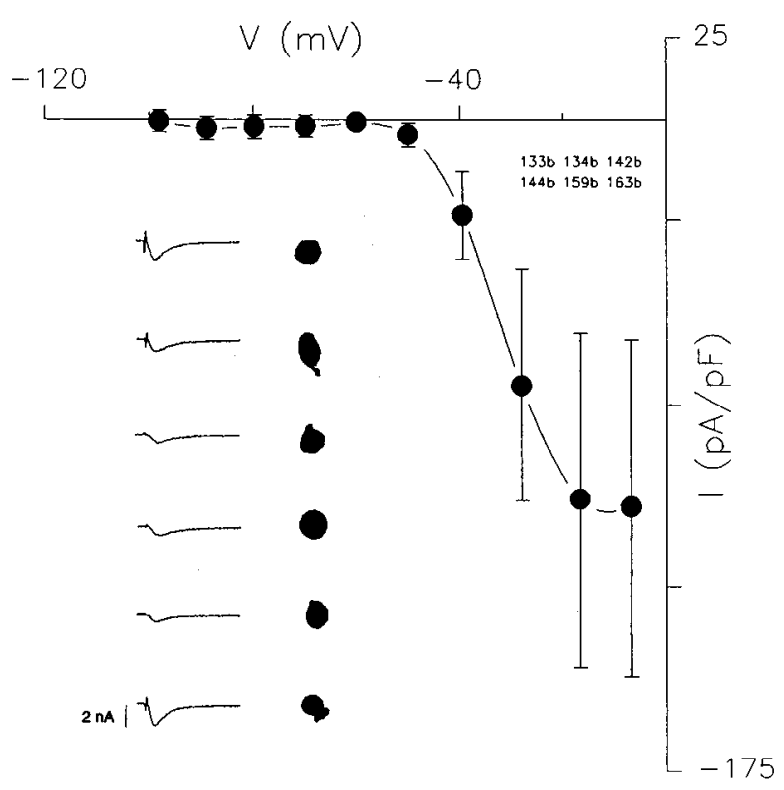

B

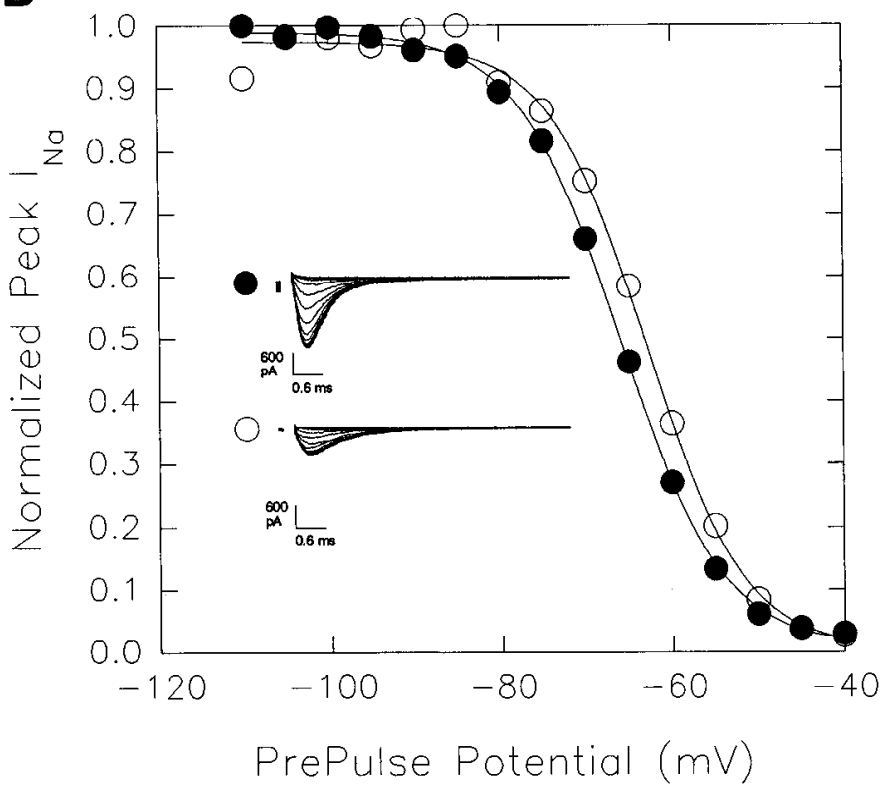

Figure 9. A, Variability of Na current magnitudes: averages and standard deviations of Na current densities versus voltage, for a group of cells $(n=6)$ that were particularly well voltage clamped. Intracellular solution contained $140 \mathrm{~mm} \mathrm{CsCl}$. Extracellular solution was modified Leibovitz with $10 \mathrm{~mm}$ TEA. Corrected for an uncompensated series resistance of $3.69 \pm 1.75 \mathrm{M} \Omega$; clamp $\tau, 38.73 \pm 25 \mu \mathrm{sec} ; \mathrm{C}_{\mathrm{m}}, 11.8 \pm$ $1.6 \mathrm{pF} ; \mathrm{R}_{\mathrm{in}}, 480 \pm 100 \mathrm{M} \Omega$. Voltage variations are within the symbol widths. Holding potential was $-80 \mathrm{mV}$; holding current was $-38 \pm 31$ pA. Inset, Current traces in response to $-10 \mathrm{mV}$ steps, and outlines of associated cell somata. Scale is $2 \mathrm{nA}$ or $15 \mu \mathrm{m}$. $B$, Steady state inactivation of $\mathrm{Na}$ currents. Two cells of high and low current densities are compared. Cells were held at $-100 \mathrm{mV}$ and prepulsed to various potentials (nominal) for $200 \mathrm{msec}$ prior to step to $-10 \mathrm{mV}$. Fits were made to a Boltzmann function. Inactivation characteristics are similar for both cells. Open circles: $z,-4.55 ; V_{h},-62.9 \mathrm{mV}$; clamp $\tau, 24 \mu \mathrm{sec}$; $R_{s}, 6.76 \mathrm{M} \Omega$. Solid circles: $z,-4.34 ; V_{h},-66 \mathrm{mV}$; clamp $\tau, 24 \mu \mathrm{sec}$; $R_{s}, 3.26 \mathrm{M} \Omega$. Intracellular solution contained $140 \mathrm{CsCl}$. Extracellular was modified Leibovitz with $10 \mathrm{mM}$ TEA and $0.1 \mathrm{mM} \mathrm{CdCl}$. Inset, Current traces for each cell.

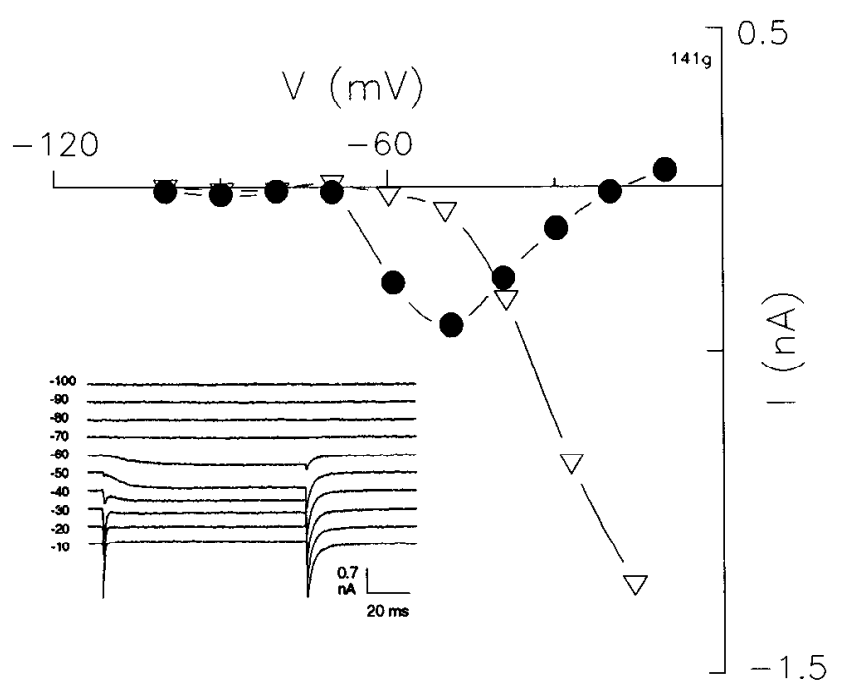

Figure 10. Simultaneous measurement of slow inward current (circles) and fast inward $\mathrm{Na}$ current (triangles) of spiral ganglion cell loaded with $140 \mathrm{~mm} \mathrm{CsCl}$, and perfused with $10 \mathrm{~mm}$ TEA Leibovitz solution. The slow inward current activates at a potential more negative than the $\mathrm{Na}$ current. Note the unusual reversal potential of the slow current $(-20$ $\mathrm{mV}$ ), indicative of charge being carried by multiple ionic species. Also note the tail currents activated during return to the holding potential. Holding potential was $-80 \mathrm{mV}$ for each trace, and the cell was stepped to the potential noted on the left of the traces. Corrected for an uncompensated series resistance of $3.3 \mathrm{M} \Omega$.

In rat retinal ganglion cells at $\sim 23^{\circ} \mathrm{C}$, peak Na currents reach half-maximal magnitude in about $500 \mu \mathrm{sec}$, and the inactivation time constant at $-20 \mathrm{mV}$, for example, is $1.3 \mathrm{msec}$ (Barres et al., 1989). These values are somewhat slower than those of the spiral ganglion cell (see Fig. 7A). Interestingly, these authors found that the kinetics of glial cells were considerably slower than retinal ganglion cells. While the $\mathbf{K}$ currents of spiral ganglion cells reach half-peak amplitude in $1 \mathrm{msec}$ at $-43 \mathrm{mV}$ at room temperature, the whole-cell $\mathrm{K}$ currents in cat retinal ganglion cells required about $1.5 \mathrm{msec}$ to reach half-peak values at $-20 \mathrm{mV}$ at $33^{\circ} \mathrm{C}$ (Lipton and Tauck, 1987). The time constant of recovery of $\mathrm{Na}$ currents from voltage-induced inactivation differs depending upon specific type of rat retinal ganglion cell, being less than or equal to $1 \mathrm{sec}$ for $\mathrm{X}$-cells and greater than $\mathrm{l}$ sec for W-cells (Kaneda and Kaneko, 1990). The average time constant of recovery for spiral ganglion cells is $2.16 \mathrm{msec}$.

Lynch and Barry (1991a) found in rat olfactory neurons that the major outward $\mathrm{K}$ conductance is a transient type that reaches half-maximal peak values within about $4 \mathrm{msec}$ at $+20 \mathrm{mV}$ $\left(\sim 21^{\circ} \mathrm{C}\right)$. These same authors also found a smaller, more slowly activating $\mathrm{K}$ current (Lynch and Barry, 1991b). In a study by Trombley and Westbrook (1991), however, only a noninactivating $\mathrm{K}$ current was found that reached half-peak amplitude at $3.75 \mathrm{msec}$ at a step potential of $+40 \mathrm{mV}$ (room temperature). These same authors measured fast inward $\mathrm{Na}$ currents that reached half-maximal peak magnitude at about $160 \mu \mathrm{sec}$. This is extremely fast and may indicate that the scale in their figure was mislabeled. In fact, the value is between 400 and $500 \mu \mathrm{sec}$ (P. Trombley, personal communication).

To my knowledge, there are no published voltage-clamp data on the conductances of mammalian taste cell primary afferents. Ilowever, in rat taste cells, some of which possess fast Na currents, half-maximal peak $\mathrm{Na}$ current is reached in about 450 $\mu \mathrm{sec}$ (room temperature; S. M. Herness, personal communica- 


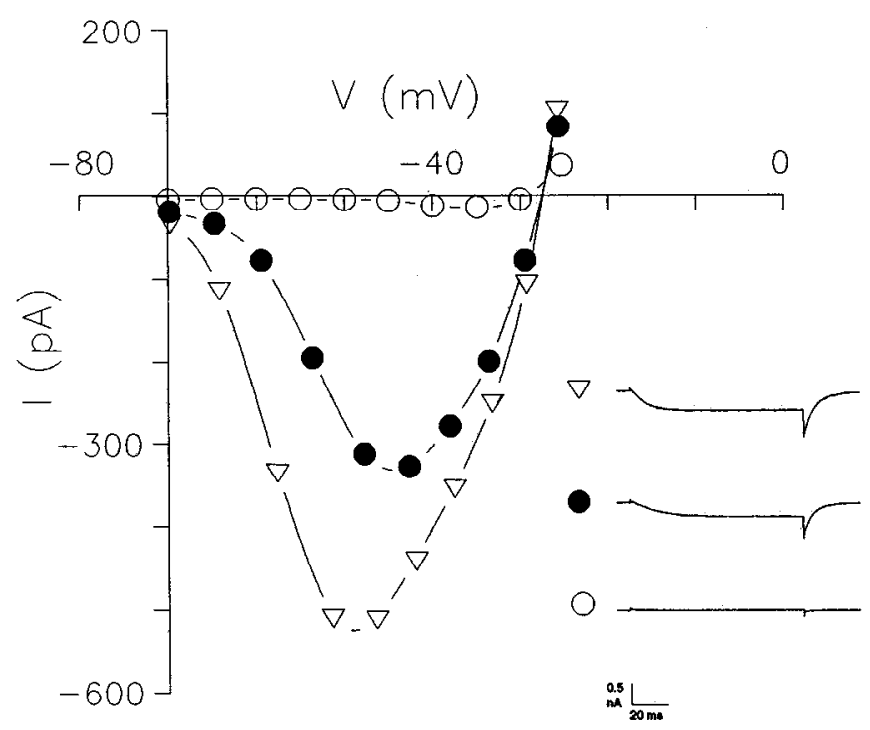

Figure 11. Reduction of slow inward currents by inorganic ions. Triangles and associated trace depict voltage dependence of sustained inward currents. Following perfusion with an additional $50 \mu \mathrm{M} \mathrm{Cd}{ }^{2+}$ (solid circles) the current magnitudes were decreased and the peak current shifted in the depolarizing direction. Treatment with $\mathrm{Gd}^{3+}(50 \mu \mathrm{M}$; open circles) totally abolishes the inward currents. Cell was perfused with normal Leibovitz medium; note that reversal potential is near $-30 \mathrm{mV}$, and does not change with $\mathrm{Cd}$ treatment. Inset, Traces depict current responses to voltage steps at $-50 \mathrm{mV}$ (nominal). Corrected for an uncompensated series resistance of $7 \mathrm{M} \Omega$. Holding potential $-80 \mathrm{mV}$. $\mathrm{CsCl}$ pipette.

tion). Interestingly, recovery of $\mathrm{Na}$ currents from voltage inactivation is quite slow, having a time constant of about 56 msec. Delayed-rectifier outward K currents reach half-maximal levels at $12.5 \mathrm{msec}$ at $0 \mathrm{mV}$.

It is clear from comparisons with spiral ganglion cell data that the channel kinetics of the cells from the mammalian visual, olfactory, and taste systems are comparatively slow. Kinetic differences probably relate to the type of stimulus each sensory system is required to detect, and the molecular method of detection (see Hille, 1992).

Yamaguchi and Ohmori (1990) studied the conductances of chick cochlear ganglion cells and observed outward $\mathrm{K}$ currents whose voltage dependence (if voltage corrections for series resistance are made for their data) is somewhat similar to the $\mathrm{K}$ conductance of the guinea pig. However, at temperatures comparable to that used in the present study, the onset kinetics of the chick's K currents are appreciably slower (see Fig. 4C). For example, voltage steps to levels above $-50 \mathrm{mV}$ require about twice as long to reach half-maximal current levels in the chick as compared to the guinea pig. While the extent of frequency sensitivity differs markedly in the guinea pig and the chick, the observed differences in the kinetics of outward $\mathrm{K}$ currents between mammalian and nonmammalian species may further reflect differences in maturity of the cells. Yamaguchi and Ohmori obtained ganglion cells from chicks between embryonic days 15 and 19, and it is possible that conductances may not exhibit adult characteristics. For example, Fuchs and Sokolowski (1990) have shown that chick cochlear hair cells do not acquire a $\mathrm{Ca}$ activated $\mathrm{K}$ conductance until after embryonic day 19. Thus, beyond species differences, it may be difficult to make direct comparisons between potentially immature cells of the chick and acutely dissociated adult cells of the guinea pig. Neverthe-
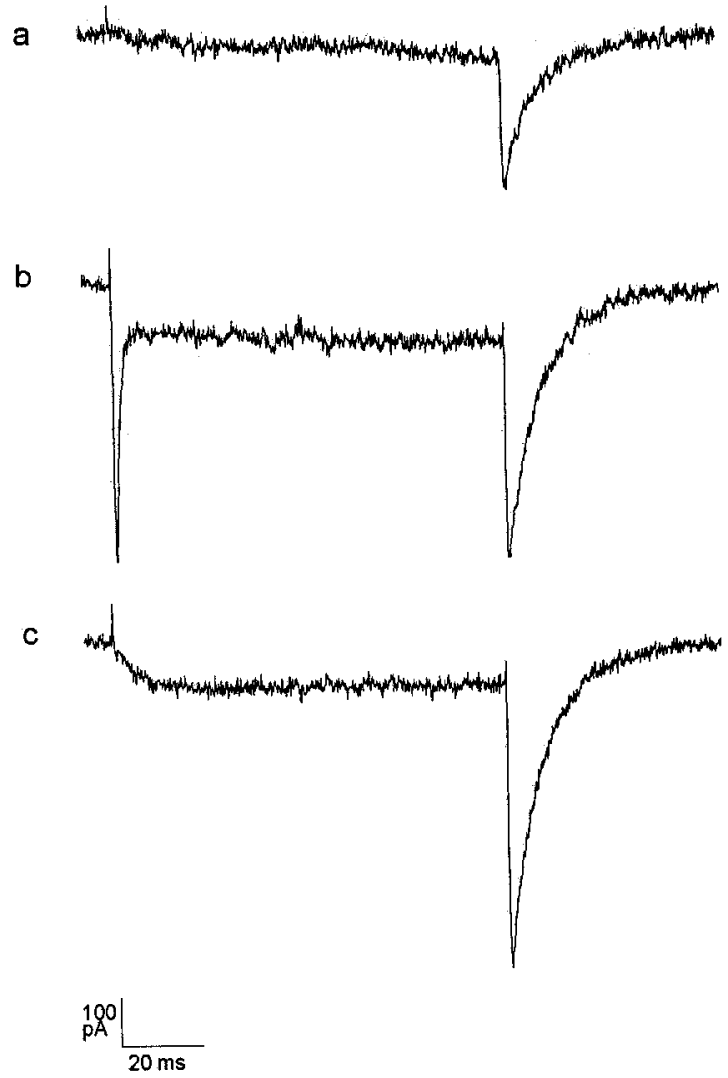

Figure 12. Effect of TTX and Na removal on fast and slow inward currents of a spiral ganglion cell. Cell was held at $-80 \mathrm{mV}$ and stepped to $-40 \mathrm{mV}$ (nominal). Trace $a$ shows response during perfusion of 10 mM TEA Leibovitz supplemented with 200 nм TTX. Trace $b$ shows response with $10 \mathrm{~mm}$ TEA Leibovitz. Trace $c$ shows response when Tris replaced all external Na. Digitally filtered at $0.1 \mathrm{msec}$. Note changes in magnitudes of tail currents. $R_{s}, 2.26 \mathrm{M} \Omega$.

less, some characteristics of the studied currents appear similar, including voltage dependence of $\mathrm{Na}$ and $\mathrm{K}$ conductances and kinetics of the Na conductance. For example, Yamaguchi and Ohmori found that the time to half-peak $\mathrm{Na}$ current ranged from 0.57 to $0.26 \mathrm{msec}$ within the voltage range of -23 to +13 $\mathrm{mV}$, and the present data ranged from 0.43 to $0.26 \mathrm{msec}$.

\section{Relevance of spiral ganglion cell conductances to eighth-nerve activity}

The electrical properties of auditory neurons help shape their response characteristics (Manis and Marx, 1991; Oertel, 1991). Indeed, the voltage dependence and kinetics of spiral ganglion cells conductances are probably highly influential. The rapidly activating $\mathrm{K}$ conductances of guinea pig spiral ganglion cells, occurring near the resting potential, will limit the duration of action potentials, and promote the rapid recovery of $\mathrm{Na}$ channels from inactivation, thereby potentially permitting higher average rates, and precise timing-traits that are requisite for auditory coding mechanisms such as phase locking.

Siegel (1992) has recorded spontaneous activity from guinea pig afferent terminals at the base of inner hair cells and speculated that possible relative refractory effects due to rapidly activated $\mathrm{K}$ conductances might account for the reduced EPSP size immediately following prior neural activity. [No spontaneous activity was found in isolated ganglion cells. Although spontaneous activity in eighth-nerve fibers can approach 140 
spikes/sec in the absence of sound, it is likely that this activity is transmitter activated, since damage to inner hair cells or treatments designed to reduce receptor current decrease or abolish spontaneous activity (Kiang et al., 1976; Sewell, 1984).] Indeed, Siegel found that spike initiation and amplitude were also reduced. Under current clamp, in the present study, the occurrence of graded depolarizing spikes with increasing current pulse magnitude reflects the rapid onset and tremendous magnitude of the outward $\mathrm{K}$ currents generated in guinea pig spiral ganglion cells - the effect of $\mathrm{Na}$ conductance activation is rapidly curtailed, and afterhyperpolarizations lasting several milliseconds ensue. Clearly, such rapid activation of $\mathrm{K}$ conductances is congruent with Siegel's findings.

Investigations of acoustically evoked eighth-nerve adaptation also reveal temporal processes that may directly relate to some of the intrinsic refractory properties of spiral ganglion cells (Westerman and Smith, 1984; Yates et al., 1985; Lutkenhoner and Smith, 1986). Peristimulus time histograms (PSTHs) of eighthnerve activity typically show a very high probability of spiking within the first few hundred microseconds following the onset of an acoustic stimulus. This is followed by a very short period of inactivity, probably reflecting the nerve's absolute refractory period. Interspike intervals in auditory nerve fibers can be as short as 0.7 msec (Kiang et al., 1965). In the gerbil, Westerman and Smith (1984) found two additional temporal components of activity decline during sustained acoustic stimulation. The rapid component had a time constant of $1-10 \mathrm{msec}$ that was level dependent (decreasing with intensity), and the slower component, which was not level dependent, had a time constant of $60 \mathrm{msec}$. Similarly, Yates et al. (1985) found two temporal processes in the guinea pig, one ranging from about $2-25 \mathrm{msec}$ that was sound-level dependent and another that had a time course greater than $100 \mathrm{msec}$. The fast form of adaptation may correspond to relative refractory periods of the spiral ganglion cell, that is, the kinetics of voltage-dependent inactivation and recovery of the $\mathrm{Na}$ conductance and $\mathrm{K}$ conductance-induced afterhyperpolarization. Another auditory neural phenomenon, forward masking, a paradigm where the response to a second tone is diminished by a prior tone, may also reflect the temporal characteristics of spiral ganglion cell ionic channel activation and inactivation. Harris and Dallos (1979) have shown that for short masking tones ( $2 \mathrm{msec}$ ) complete recovery of firing rate occurs within $20 \mathrm{msec}$. This process is also level dependent. While it is tempting to make comparisons between these fast level-dependent processes and the voltage-dependent characteristics of $\mathrm{Na}$ and $\mathrm{K}$ conductances in ganglion cells, the more slowly developing decline in fiber rate probably reflects synaptic events (transmitter rundown, hair cell calcium current kinetics) or discharge history effects (Smith and Brachman, 1982; Lutkenhoner and Smith, 1986; Kidd and Weiss, 1990). For example, it is conceivable that prior neural activity may increase extracellular $\mathrm{K}$, thereby inactivating $\mathrm{Na}$ channels through depolarizing effects. Perhaps some of the longer adaptation time constants reflect the time constants of ionic recovery mechanisms, for example, pump activities and $\mathrm{K}$ sinking through supporting cells (Santos-Sacchi, 1991b).

\section{Slow inward currents}

The slow inward current observed in Cs-loaded cells may partially consist of a $\mathrm{Ca}$ component, since $\mathrm{Cd}^{2+}, \mathrm{Gd}^{3+}$, and $\mathrm{Co}^{2+}$ in the absence of $\mathrm{Ca}^{2+}$ are blockers. $\mathrm{Gd}^{3+}$ has been shown to block both sustained and transient $\mathrm{Ca}$ currents in cerebellar granule cells (Slesinger and Lansman, 1991) but only transient Ca currents in NG108-15 cells (Docherty, 1988). Nonetheless, the sustained inward current displays many puzzling features, including its voltage dependence and reversal potential. One difficulty encountered in this study was the incomplete block of outward currents by Cs loading, even with the addition of 10 mM TEA extracellularly. While it is known that Cs can permeate Ca channels (Fenwick et al., 1982), and while this may be occurring to some extent in spiral ganglion cells, it appears that the use of Cs does not lead to complete isolation of Ca currents, as it does in some cell types (e.g., Kinnamon et al., 1989; Fuchs et al., 1990). Indeed, Dryer et al. (1991) have documented that Ca currents are not adequately isolated in chick ciliary ganglion cells when using intracellular $\mathrm{Cs}$ and extracellular $\mathrm{K}$ channel blockers. Ca conductances in the spiral ganglion cell of the guinea pig require further in-depth characterization, utilizing more aggressive current isolation techniques.

It is interesting to note that Wilson et al. (1991) have described a TTX-blockable voltage-dependent inward current in bag cell neurons of Aplysia that is activated by venom from Conus textile. It is carried mainly by $\mathrm{Na}$, activates near $-60 \mathrm{mV}$, and reverses near zero potential. This current appears to have some similarities with other $\mathrm{Ca}$-activated nonspecific cation currents (Partridge and Swandulla, 1988). Despite the observation that the slow inward current in spiral ganglion cells is not $\mathrm{Na}$ dependent, it is noteworthy that it shares some of the characteristics of the bag cell neuron current; namely, it shares a similar TTX sensitivity, activation potential, and reversal potential, which indicates permeation by multiple ionic species.

\section{Summary}

It is becoming increasingly clear that the ability of the auditory system to process high-frequency acoustic events reflects the underlying rapid kinetics of the system's constituent cells. Within the sensory epithelium, mechanical events are remarkable. The mechanical transduction mechanism in hair cells utilizes one of the fastest gating processes known (Corey and Hudspeth, 1983), and outer hair cell voltage-dependent mechanical responses are measurable in the kilohertz range (Santos-Sacchi, 1992). The $K$ conductance in inner hair cells is appropriately very rapid in onset (Santos-Sacchi, 1989b; Kros and Crawford, 1990), as are those in cells of the cochlear nucleus (Manis and Marx, 1991). It is no wonder that the observed membrane properties of the spiral ganglion cells that join peripheral receptors to central targets are also fast.

\section{References}

Armstrong CM, Miller C (1990) Do voltage-dependent $\mathrm{K}^{+}$channels require $\mathrm{Ca}^{2+}$ ? A critical test employing a heterologous expression system. Proc Natl Acad Sci USA 87:7579-7582.

Baker M, Bostock H, Grafe P, Martius P (1987) Function and distribution of three types of rectifying channel in rat spinal root myelinated axons. J Physiol (Lond) 383:45-67.

Barres BA, Chun LLY, Corep DP (1989) Glial and neuronal forms of the voltage-dependent sodium channel: characteristics and cell-type distribution. Neuron 2:1375-1388.

Barrett EF, Barrett JN (1982) Intracellular recording from vertebrate myelinated axons: mechanism of the depolarizing afterpotential. $\mathbf{J}$ Physiol (Lond) 323:117-144.

Black JA, Kocsis JD, Waxman SG (1990) Ion channel organization of the myelinated fiber. Trends Neurosci 13:48-54.

Chiu SY, Ritchie JM (1984) On the physiological role of internodal potassium channels and the security of conduction in myelinated nerve fibers. Proc R Soc Lond [Biol] 220:415-422.

Chiu SY, Schwartz W (1987) Sodium and potassium currents in acute- 
ly demyelinated internodes of rabbit sciatic nerves. J Physiol (Lond) 391:631-649.

Corey DP, Hudspeth AJ (1983) Kinetics of the receptor current in bullfrog saccular hair cells. J Neurosci 3:962-976.

Dallos P (1988) Cochlear neurobiology. In: Auditory function: neurobiological bases of hearing, pp 153-188. New York: Wiley.

Dallos P, Santos-Sacchi J, Flock $\AA$ (1982) Intracellular recordings from outer hair cells. Science 218:582-584.

David G, Barrett JN, Barrett EF (1992) Evidence that action potentials activate an internodal potassium conductance in lizard myelinated axons. J Physiol (Lond) 445:277-301

Davis RL, Mroz EA, Sewell WF (1989) Properties of single channels under the myelin sheath in goldfish auditory neurons. Paper presented at midwinter meeting of the Association for Research in Otolaryngology, St. Petersburg, FL, February.

Docherty RJ (1988) Gadolinium selectively blocks a component of calcium current in rodent neuroblastoma $\times$ glioma hybrid (NG10815) cells. J Physiol (Lond) 398:33-47.

Dryer SE, Dourado MM, Wisgirda ME (1991) Properties of $\mathrm{Ca}^{2+}$ currents in acutely dissociated neurons of the chick ciliary ganglion: inhibition by somatostatin-14 and somatostatin-28. Neuroscience 44: $663-672$

Fenwick EM, Marty A, Neher E (1982) Sodium and calcium channels in bovine chromaffin cells. J Physiol (Lond) 331:599-635.

Frankenhaeuser B, Moore LE (1963) The effect of temperature on the sodium and potassium permeability changes in myelinated nerve fibers of Xenopus laevis. J Physiol (Lond) 169:431-437.

Fuchs PA, Sokolowski BH (1990) The acquisition during development of Ca-activated potassium currents by cochlear hair cells of the chick. Proc R Soc Lond [Biol] 241:122-126.

Fuchs PA, Evans MG, Murrow BW (1990) Calcium currents in hair cells isolated from the cochlea of the chick. J Physiol (Lond) 429; 553-568.

Gilley WF, Lucero MT, Horrigan FT (1990) Control of the spatial distribution of sodium channels in giant fiber lobe neurons of the squid. Neuron 5:663-674.

Harris D, Dallos P (1979) Forward masking of auditory nerve fiber responses. J Neurophysiol 42:1083-1107.

Hille B (1992) Ionic channels of excitable membranes. Sunderland, MA: Sinauer.

Hodgkin AL, Huxley AF (1952) A quantitative description of membrane current and its application to conduction and excitation in nerve. J Physiol (Lond) 117:500-544.

Huguenard JR, Coulter DA, Prince DA (1991) A fast transient potassium current in thalamic relay neurons: kinetics of activation and inactivation. J Neurophysiol 66:1304-1315.

Javel E (1986) Basic response properties of auditory nerve fibers. In: Neurobiology of hearing: the cochlea (Altschuler RA, Hoffman DW, Bobbin RP, eds). New York: Raven.

Kaneda M, Kaneko A (1990) $I_{\mathrm{Na}}$ of cat ganglion cells: the time course of recovery from inactivation is related to soma size. Jap $\mathrm{J}$ Physiol Suppl 40:\$177.

Kellerhals B, Engstrom H, Ades HW (1967) Die Morphologie des Ganglion Spirale Cochlea. Acta Otolaryngol [Suppl] 226:1-78.

Kiang NY-S, Watanabe T, Thomas C, Clark LF (1965) Discharge patterns of single fibers in the cats auditory nerve. Cambridge, MA: MIT Press.

Kiang NY-S, Liberman MC, Levine RA (1976) Auditory-nerve activity in cats exposed to ototoxic drugs and high intensity sounds. Ann Otol Rhinol Laryngol 85:752-768.

Kidd RC, Weiss TF (1990) Mechanisms that degrade timing information in the cochlea. Hear Res 49:181-208.

Kimura RS, Bongiorno CL, Iverson NA (1987) Synapses and ephapses in the spiral ganglion. Acta Otolaryngol [Suppl] 438:1-18.

Kinnamon SC, Cummings TA, Roper SD, Beam KG (1989) Calcium currents in isolated taste receptor cells of the mudpuppy. Ann NY Acad Sci 560:112-115.

Kros CJ, Crawford AC (1990) Potassium currents in inner hair cells isolated from the guinea pig. J Physiol (Lond) 421:263-291.

Lipton SA, Tauck DL (1987) Voltage-dependent conductances of solitary ganglion cells dissociated from the rat. J Physiol (Lond) 385: 361-391.

Lutkenhoner B, Smith RL (1986) Rapid adaptation of auditory-nerve fibers: fine structure at high intensities. Hear Res 24:289-294.

Lynch JW, Barry PH (1991a) Properties of transient $\mathrm{K}^{+}$currents and underlying single $\mathrm{K}^{+}$channels in rat olfactory receptor neurons. J Gen Physiol 97:1043-1072.

Lynch JW, Barry PH (1991b) Slowly activating $\mathrm{K}^{+}$channels in rat olfactory receptor neurons. Proc R Soc Lond [Biol] 244:219-225.

Manis PB, Marx SO (1991) Outward currents in isolated ventral cochlear nucleus neurons. J Neurosci 11:2865-2880.

Marty A, Neher E (1983) Tight-seal whole-cell recording. In: Singlechannel recording (Sakmann B, Neher E, eds), pp 107-122. New York: Plenum.

Mathias RT, Levis RA, Eisenberg RS (1981) An alternative interpretation of charge movement in muscle. In: The regulation of muscle contraction: excitation-contraction coupling. New York: Academic.

Oertel D (1991) The role of intrinsic neuronal properties in encoding of auditory information in the cochlear nuclei. Curr Opin Neurobiol $1: 221-228$.

Ota CY, Kinura RS (1980) Ultrastructural study of the human spiral ganglion. Acta Otolaryngol 89:53-62.

Palmer AR, Russell IJ (1986) Phase-locking in the cochlear nerve of the guinea pig and its relation to the receptor potential of inner haircells. Hear Res 24:1-15.

Partridge LD, Swandulla D (1988) Calcium-activated non-specific cation channels. Trends Neurosci 11:69-72.

Robertson D (1976) Possible relation between structure and spike shapes of neurones in the guinea pig cochlear ganglion. Brain Res 109:487-496.

Ruggero MA (1992) Physiology of the auditory nerve. In: The mammalian auditory pathway: neurophysiology (Popper AN, Fay RR, eds), pp 34-93. New York: Springer.

Russcll IJ, Sellick PM (1978) Intraccllular studics of hair cells in the mammalian cochlea. J Physiol (Lond) 284:261-290.

Santos-Sacchi J (1989a) Whole-cell voltage clamping of spiral ganglion and outer hair cells. Paper presented at Hearing and Chemical Senses Seminars, Kresge Hearing Research Institute, University of Michigan, Ann Arbor, MI, April.

Santos-Sacchi J (1989b) Asymmetry in voltage dependent movements of isolated outer hair cells from the organ of Corti. J Neurosci 9:29542962.

Santos-Sacchi J (1989c) Calcium currents, potassium currents and the resting potential in isolated outer hair cells. Paper presented at the midwinter meeting of the Association for Research in Otolaryngology, St. Petersburg, FL, February.

Santos-Sacchi J (1990) Studies on the fast inward $\mathrm{Na}^{+}$current in isolated type I spiral ganglion cells. Paper presented at midwinter meeting of the Association for Research in Otolaryngology, St. Petersburg, FL, February.

Santos-Sacchi J (1991a) Reversible inhibition of voltage dependent outer hair cell motility and capacitance. J Neurosci 11:3096-3110.

Santos-Sacchi J (1991b) Isolated supporting cells from the organ of Corti: some whole cell electrical characteristics and estimates of gap junctional conductance. Hearing Res 52:89-98.

Santos-Sacchi J (1992) On the frequency limit and phase of outer hair cell motility: effects of the membrane filter. J Neurosci 12:1906-1916.

Sewell (1984) The relation between the endocochlear potential and spontaneous activity in auditory nerve fibers of the cat. $J$ Physiol (Lond) 347:685-696.

Siegel JH (1992) Spontaneous synaptic potentials from afferent terIninals in the guinea pig cochlea. Hear Res 59:85-92.

Siegel JH, Dallos P (1986) Spike activity recorded from the organ of Corti. Hear Res 22:245-248.

Slesinger PA, Lansman JB (1991) Inactivation of calcium currents in granule cells cultured from mouse cerebellum. J Physiol (Lond) 435: 101-121.

Smith RL, Brachman ML (1982) Adaptation in auditory nerve fibers: a revised model. Biol Cybern 44:107-120.

Spoendlin H (1971) Degeneration behavior of the cochlear nerve. Arch Klin Exp Ohrennasen Kehlkopfheilkd 200:275-291.

Spoendlin H (1988) Neural anatomy of the inner ear. In: Physiology of the ear (Jahn A, Santos-Sacchi J, eds), pp 201-219. New York: Raven.

Trombley PQ, Westbrook GL (1991) Voltage-gated currents in idenlified rat olfactory receptor neurons. J Neurosci 1 1:435-444.

Waxman SG, Ritchie JM (1985) Organization of ion channels in the mammalian nerve fiber. Science 228:1502-1507.

Westerman LA, Smith RL (1984) Rapid and short-term adaptation in auditory nerve responses. Hear Res 15:249-260. 
Wilson GF, Fisher TE, Joiner WJ, Olivera BM, Kaczmarek LK (1991) Venom from Conus textile activates a tetrodotoxin-sensitive inward current in bag cell neurons of Aplysia. Soc Neurosci Abstr 17:955.

Yamaguchi K, Ohmori H (1990) Voltagc-gated and chemically gatcd ionic channels in the cultured cochlear ganglion neurone of the chick J Physiol (Lond) 420:185-206.

Yates GK, Robertson D, Johnstone BM (1985) Very rapid adaptation in the guinea pig auditory nerve. Hear Res 17:1-12. 